Relations industrielles

Industrial Relations

\title{
Workplace Democracy and Social Change, by Frank Lindenfeld and Joice Rothschild-Whitt, eds, Boston, Porter Sargent Publication, 447 pages, ISBN 0-87558-102-1.
}

\section{Alexander J. Matejko}

Volume 38, numéro 3, 1983

URI : https://id.erudit.org/iderudit/029394ar

DOI : https://doi.org/10.7202/029394ar

Aller au sommaire du numéro

Éditeur(s)

Département des relations industrielles de l'Université Laval

ISSN

0034-379X (imprimé)

1703-8138 (numérique)

Découvrir la revue

Citer ce compte rendu

Matejko, A. J. (1983). Compte rendu de [Workplace Democracy and Social Change, by Frank Lindenfeld and Joice Rothschild-Whitt, eds, Boston, Porter Sargent Publication, 447 pages, ISBN 0-87558-102-1.] Relations industrielles / Industrial Relations, 38(3), 687-688. https://doi.org/10.7202/029394ar

Tous droits réservés ( Département des relations industrielles de l'Université Laval, 1983
Ce document est protégé par la loi sur le droit d'auteur. L'utilisation des services d'Érudit (y compris la reproduction) est assujettie à sa politique d'utilisation que vous pouvez consulter en ligne.

https://apropos.erudit.org/fr/usagers/politique-dutilisation/ 
Workplace Democracy and Social Change, by Frank Lindenfeld and Joice Rothschild-Whitt, eds, Boston, Porter Sargent Publication, 447 pages, ISBN 0-87558-102-1

This is a valuable collection of writings on the characteristics of organizational democracy, the role of an individual in it, large-scale workers cooperatives, selfmanaged collectives, and social change initiated by the workplace democracy projects.

According to J. Rothschild-Whitt, the collectivist-democratic organization is characterised by: the authority resident in the collectivity as a whole, minimal stipulated rules, wholistic human relations, collectivistic and informal social controls, social selection of the personnel, abolishment of the hierarchy of positions, primary importance of the normative and solidary incentives, egalitarian allocation of rewards, minimal division of labour, wholistic roles, and the rotational nature of the coordinative functions.

To establish such organization takes much time and patience; people from the beginning have to share enough common values; it is necessary to be prepared for emotional intensity arising, among others, from the lack of an adequate socialization among people; the external environment is very often unsuitable to accept or at least tolerate the new type organization.

P. Bernstein enumerates the following necessary elements for an effective worker participation in decision-making: a particular mix of managerial authority and democratic control adequate to the given circumstances, access of employees to and sharing of management level information, guaranteed protection of the employee from reprisals for voicing criticisms, an independent board of appeals to settle disputes, consciousness open to cooperation, return to participating employees of at least a portion of the surplus.

It is worth to add that the competence of participants in the subject of their participation, as well as a vital importance of this sub- ject to them, both seem to be very important. Such participation which is arranged for people but not by people does not have much chance to succeed. The trust relationships are necessary in order to have a genuine participation. On the other hand, the practice of participatory decision making in the matters of a vital importance to workers reinforces the mutual trust.

Another factor worth to be mentioned here is the mutual importance of good coordination and a trustful participation. Any lack of coordination may influence negatively the ability and the willingness of people to participate. On the other hand, participation as such is not a magic recipe for smooth coordination. The elimination of management function due to participation seems to be a common naiveté among the enthusiasts of workplace democracy. It is true that due to participation the management may become considerably democratized. However, this is not identical with its automatic elimination from the workplaces.

Under the workplace democracy people are supposed to gain an increasing sense of autonomy, competence, and personal identity. The evidence reported in the book shows that even in refuse collection democratically organized this is quite possible. Another question is whether people are willing to make enough organizational commitment and readiness to solve the interpersonal problems in a peaceful manner. Fear of conflict does not disappear in face-to-face democracies, as this is evidenced by J.J. Mansbridge.

The ownership of production means by workers can allow the exploitation of the hired labour or selling off the firm when this suits the present owners, as may be seen in the case of the U.S. plywood cooperatives. The worker-managed insurance company described by D. Zwerling shows that people do not always want to take an active part in running the business; they even may treat as undemocratic the insistence of the leaders to practice participatory democracy. 
The coops generally suffer undercapitalization and lack of skilled management; in order to save the cost coops depend on voluntary work and the underpaid personnel, but this may undermine their efficiency and competitiveness. There is a great need to train a democratically oriented management personnel as well as to form federations able to help each coop in the case of any trouble.

Such problems as the delegation of power, consensus vs. majority voting, and worker control vs. community and client control (see the contribution by F. Lindenfeld, pp. 257-269) create several difficulties also in the alternative organizations. "Conflicts of interest between workers and clients, managers and members, are inevitable even in alternative organizations, and cannot necessarily be eliminated. It helps to institutionalize mechanisms whereby such conflicts can be resolved» (p. 268). "Democratic organizations must continue to be sensitive to the perennial problems of institutionalization and oligarchization and must pay attention to the factors that would help them resist these problems» (p. 295).

The future of workplace democracy in North America is very much related to the growing expectations among people to enjoy freedoms at work. D. Ellerman offers the model of a workers' cooperative corporation. According to him, the net book value must be partitioned off from the membership rights by the system of internal capital accounts. F. Lindenfeld suggests that the workers' cooperatives may save many jobs where plants are closing. G. Alperovitz and J. Faux discuss the necessity of a substantial government backing for the proposed community steel company in Youngstown.

R.M. Kanter, B.A. Stein and D.W. Brinkenhoff discuss the kinds of vehicles that make possible for industrial workers to reform their own work by considering work and quality of work life in the context of organizational structure reform. The parallel structure gradually established on the side of the existing bureaucratic structure offers new opportunities for working people as well as for management. "It is the creation of a parallel structure that constitutes the central reform and the major change» (p. 379).

C.G. Benello expects the organized labour to serve as an important lobbying force to introduce legislation favoring worker management as a solution to unemployment (p. 395). He is aware of the difficulty to gain the support of the North American trade union leaders for this idea. A. Gorz argues for a broad political, strategic and theoretical vision which would adequately reinforce the strive for workers' control.

A critical evaluation of workplace democracy projects is one of the main assets of the book here under review. Only by gaining a good insight into the problems met during the implementation of these projects it is possible to improve the general performance in this subtle field. So far there has been too much uncritical enthusiasm and false expectations doing more harm than good to all those who take seriously the alternative forms of organization.

There is a great need to have more studies of the same kind as presented in the book allowing to formulate directives how to make workplace democracy really working well and offering benefits for the whole society. The idea of a parallel structure mentioned above seems particularly attractive and worth to be considered as an inspiration of new developments.

\section{Alexander J. MATEJKO}

University of Alberta 